that no further dialysis was necessary. This is a contrast with recent experience in Great Britain, where $20 \%$ of grafts failed to function at any time, ${ }^{32}$ and a reminder that the barriers to successful transplantation are not all immunological.

Probably the biggest help to the success of cadaver grafting in Britain would be the widespread use of lung ventilators during the last few hours of life in potential donors. ${ }^{32}$ In most developed countries of the world it has been accepted that death by turning off a ventilator is no less dignified than slow demise by asphyxia, but opinion in this country is still divided on this subject. Further improvement can be expected from the use of antilymphocyte globulin (ALG), which has been employed as a routine in some units with success. ${ }^{33}$ Two preparations at least have passed the test of controlled trial, ${ }^{34} 35$ and a national trial is planned for the long awaited British ALG.

For the moment our hopes are pinned on better matching of donor and recipient, and it is heartening to hear that twothirds of the transplants reported to Bristol have resulted from exchange of kidneys between participating British centres. ${ }^{8}$ The time during which the ischaemic kidney is chilled is much less critical than the initial warm ischaemia time, and the few hours required to transport kidneys within these small islands should be more than adequately compensated by the closer matching that results. 32 Unfortunately HL-A matching does not predict the results of cadaver grafts as well as those from living donors, ${ }^{4}$ so this policy alone is unlikely to resolve the nephrologist's dilemma entirely, but some recent observations may open up a new approach. Patients who form cytotoxic antibodies against one HL-A antigen have an increased liability to reject grafts without this antigen despite a negative cross-match. ${ }^{36}$ On the other hand, some patients do not produce cytotoxic antibodies even after repeated stimulation by transfusion, and these are also unlikely to reject a graft on the present techniques of immunosuppression. ${ }^{37}$ If tests can be devised to detect these "rejectors" and "non-rejectors" in advance, the decision whether to accept a midnight offer of a transplant will be made easier for at least some patients and their physicians.

\footnotetext{
1 Murray, J. E., Barnes, B. A., and Atkinson, J. C., Transplantation, 1971,

11, 328. F. M., Brunner, F. P., Gurland, H. J., and Harlen, H., in Proceedings of the European Dialysis and Transplant Association, 8, 3. Proceedings of the Europed

8 Patel, R., and Myrberg, S., British Medical Fournal, 1970, 4, 709.

- Hors, J., Feingold, N., Fradelizi, D., and Dausset, J., Lancet, 1971, 1, 609.

- Department of Health and Social Security Report to Dialysis Centres, 1971.

- McGeown, M. G., Lancet, 1972, 1, 307.

Pendreigh, D. M., et al., Lancet, 1972, 1, 304.

8 Nelson, S. D., unpublished.

- British Medical fournal, 1963, 1, 899.

10 British Medical fournal, 1963, 2, 633.

11 Calne, R. Y., Loughridge, L. W., MacGillivray, J. B., Zilva, J. F., and Levi, A. J., British Medical fournal, 1963, 2, 645.

12 Parsons, F. M., Markland, C., Raper, F. P., and Fox, M., British Medical Fournal, 1963, 1, 930.

13 Porter, K. A., et al., British Medical fournal, 1963, 2, 639.

14 Starzl, T. E., et al., Annals of Surgery, 1970, 172, 1 .

15 Rees, R. W. M., Proceedings of the Royal Society of Medicine, 1972, 65, 473.

16 Hadjiyannakis, E. J., Evans, D. B., Smellie, W. A. B., and Calne, R. Y. Lancet, 1971, 2, 781 .

17 Gordon, E. M., Johnson, A. G., and Williams, G., Lancet, 1972, 1, 226.

18 Powis, S. J. A., Barnes, A. D., Dawson-Edwards, P., and Thompson, H., British Medical fournal, $1972,1,99$.

10 Spencer, E. S., and Andersen, H. K., British Medical Fournal, 1970, 3, 251.

Cohen, M. L., Weiss, E. B., and Monaco, A. P., American fournal of Medicine, 1971, 50, 269.

21 Sussman, M., and Russell, R. B., Proceedings of the Royal Society of Medicine, 1972, 65, 471 .

22 Morris, P. J., et al., Medical Fournal of Australia, 1971, 1, 1255.

23 Hood, B., Ölander, R., Nagy, Z., and Bergentz, S. E., Scandinavian Fournal of Urology and Nephrology, 1970, 4, 135.

4 Starzl, T. E. et al., Annals of Surgery, 1970, 172, 437.

24 Starzl, T. E., et al., Annals of Surgery, 1970, 172,

so Evarts, C. M., and Phalen, G. S., Clinical Orthopaedics, 1971, 78, 330.

87 Yadav, R. V. S., Marshall, V. C., Johnson, W., Mathew, T. H., and Yadav, R. V. S., Marshall, V. C., Johnson, W., Mathew, T.

so Golby, M., Transplantation, 1970, 10, 201.
}

"Fine, R. N., et al., Lancet, 1971, 1, 1087.

80 Elstein, M., Smith, E. K. M., and Curtis, J. R., British Medical Fournal,

1969, 2, 734. 1 Marshall, V., Kincaid-Smith, P., Morris, P. J., Saker, B., and Eremin, J., Lancet, 1968, 2, 927.

2a Festenstein, H., et al., Lancet, 1971, 2, 225.

Simmons, R. L., Kjellstrand, C. M., Buselmeier, T. J., and Najarian, J. S., Archives of Surgery, 1971, 103, 290.

* Sheil, A. G. R., et al., Lancet, 1971, 1, 359.

as Birtch, A. G., et al., Transplantation Proceedings, 1971, 3, 762.

Patel, R., Merrill, J. P., and Briggs, W. A., Nero England foumal of Medicine, 1971, 285, 274.

27 Opelz, G., Mickey, M. R., and Terasaki, P. I., Lancet, 1972, 1, 868.

\section{Objectives of Research}

Last week's White Paper ${ }^{1}$ on Government-financed research is based on several misconceptions that are particularly glaring when the position of the Medical Research Council is considered. The first of them, stated early on, is the foundation of the White Paper's policy and is a familiar declaration in political circles: "Objectives are set by the Cabinet." Anyone looking back over the Medical Research Council's vast contributions to medicine during the last 50 years may be forgiven for wondering how many of its objectives were actually set by the Cabinet of the day-or any day.

This absurdity springs from a problem that is increasingly troublesome to Governments financing research, for in allocating the tax payers' money to this end a Government cannot define the objectives that should be sought except in terms so wide as to be virtually meaningless. Scientific research, like politics, is quite largely the art of the possible. And the people who know what may or may not be possible are the research workers familiar with the question. Every sensible person wants better health, better care if he falls ill, and better medical, surgical, or psychiatric treatment. We all want cures for cancer, backache, schizophrenia, and the common cold. These objectives do not need defining, and we may guess that the Cabinet has devoted very little time to their definition. But a continual recomnaissance goes on from areas of knowledge into areas of ignorance, and the people doing this, as well as their associates and the directors of their departments, are assessing progress and reconsidering the likelihood of reaching an objective by the approach taken. One person advances, another is baffled. But the aims of medical research are self-evident, and for many years they have been amply served by the traditional method of entrusting money to a research council independent of the Government but directed and staffed by scientists of outstanding ability.

The aim now is to introduce the so-called customer/ contractor approach. This means that Government Departments, as customers, define their requirements. Contractors -the research councils-advise on the feasibility of meeting them and undertake the work. And the arrangements must be such that the objectives remain attainable within reasonable cost. The last is a natural proviso. It is the relationship between a Government Department as customer and a research council as contractor that is unrealistic in the medical field, though it may have some applicability to, say, defence.

To convert the Department of Health and Social Security and the Scottish Home and Health Department into customers the White Paper proposes to allocate to them some of the money at present going direct to the M.R.C. from the Department of Education and Science. In 1971-2 the M.R.C. was allotted $£ 22.4 \mathrm{~m}$. The amounts to be subtracted from 
this and allocated to the Health Departments in each of the three years from $1973-4$ are: $£ 2.75 \mathrm{~m}$., $£ 4.25 \mathrm{~m}$., and $£ 5.5 \mathrm{~m}$. On these sums the White Paper includes this declaration of intent-or at least pious hope: "No conditions will be placed on the use of the money transferred to customer Departments, but the expectation is that it will be spent to commission applied research work from the Research Councils." Since the M.R.C. supports a large number of research units, mostly on long-term projects, a reasonable stability in its financing from year to year is essential. To put a substantial proportion of its budget at the disposal of "customer" Departments is bound to disturb its plans. Thus the amount of disturbance and the harm it may or may not do to medical research in this country will clearly depend to a large extent on how these Departments conduct their affairs. Certainly there is no evidence that they are or could be any more aware of what objectives should be aimed at in medical research than the M.R.C. has shown itself to be.

1 Framework for Government Research and Development, Cmnd. 5046. London, H.M.S.O., 1972 (13p net).

\section{Six Months' Grace ... and Other Matters}

In 1965 the G.M.C.'s proposal to introduce an annual retention fee $^{1}$ was an insignificant cloud in an already stormy medicopolitical sky, but over seven years the G.M.C. affair has grown to such thundercloud proportions that it now threatens the Health Service. This became clear when a few days before the Annual Representative Meeting the G.M.C. announced its intention to strike off those doctors who had refused to pay the fee and the dispute became an explosive topic at Southampton (see Meeting Report, Supplement, p. 71).

What has bedevilled the search for a mutually acceptable solution to the controversy within the profession over the G.M.C.'s functions, constitution, and finance is that as a statutory body with legally defined functions the G.M.C. has been having to cope with an essentially political situation. Adjustment and compromise which come naturally to a political body like the B.M.A.-are not so familiar to the G.M.C. It is to its credit that the G.M.C. has been prepared to discuss the profession's complaints about its workings and move some way towards meeting these. Nevertheless, some doctors, particularly the juniors, see it as so often moving too little and too late. Last week, however, in the eyes of the Representative Body it had moved too clumsily, too soon. Having sensibly deferred removing non-paying doctors from the Register while it thrashed out with the B.M.A. and the Government a new constitution $^{2}$ (and while an independent financial inquiry was held ${ }^{3}$ ), it was an act of political naivety for the G.M.C. to announce it was despatching final notices to those doctors ${ }^{4}$ just as discussions were starting on the third leg of the profession's trilogy of criticism-the G.M.C.'s functions.

In the circumstances the reasonable but firm reaction of the representatives showed they wanted a responsible, constructive approach. Speakers were tough but they spurned polemics, and Mr. Walpole Lewin's explanation of the present situation (in which he shed some much needed light on the numbers of non-paying doctors) helped the meeting towards that goal. He told representatives, too, that as a result of the G.M.C.'s action he would shortly be meeting the Chief Medical Officer to discuss the implications for the N.H.S. and the defence societies on the likely consequences. for individual doctors.

The outcome of the two-hour debate was agreement that the B.M.A. should give six months' grace for an agreed report on the G.M.C.'s functions to be presented. Failing this, the Representative Body decided that "the members of the B.M.A. and all other registered medical practitioners would be justified in withholding the annual retention fee, and that the B.M.A. should then petition the Government to initiate an independent inquiry into the composition and functions of the G.M.C."

With voices rarely raised in passion, the rest of the meeting was generally a quiet procession of debates, but these ranged far and wide. The Review Body and the Industrial Relations Act-even N.H.S. reorganization, Seebohm excepted-came and went if not quite unnoticed, certainly unsung. Perhaps the recent craft conferences ${ }^{5-7}$ and Special Representative Meetings past and pending partly explained the unaccustomed calm during these sections of the agenda.

Whatever the reasons it did not prevent representatives from looking overseas to the dilemma of their colleagues in South Africa. Stirred by a pertinent speech from a young Englishwoman recently returned from working in a South African hospital, the meeting overwhemingly reaffirmed its belief that "the representation of doctors, their pay, conditions of employment, and availability of posts should not be unreasonably affected by consideration of colour, race, creed, or sex." It then went on to urge the Medical Association of South Africa to do everything possible to install the colour equality of all members of the medical profession in South Africa.

Still looking "overseas" (at least until January 1973) the Representative Body discussed the E.E.C. and, though welcoming the mutual recognition of degrees within Europe, urged the Government to negotiate inclusion of "assessment of linguistic competence" for doctors migrating within the Community. The future of the N.H.S. in the European Community and the problems of specialist registration were other subjects which plainly worried speakers. However, the meeting accepted the Council's report on its extensive work on behalf of the profession in this-to most doctors-largely unfamiliar territory. ${ }^{8}$

Practical experience of the Seebohm changes 9 has not lessened doctors' forebodings about the adverse effect these would have on their patients. The profession's disquiet came over strongly during the debates on the local authority health and social services. Of course it is easy-and dangerous-to found criticism on selected individual cases, and certainly some disturbing instances were mentioned by speakers of the results of removing social workers from the health departments' control. But there was little doubt that the meeting believed there is a growing serious problem here.

Doctors in all branches are understandably worried lest the divisions created by the social work legislation damage the potential benefits of N.H.S. integration in 1974. Both Government and Opposition seem wedded to Seebohm, but they should not close their minds to looking again at the relations between medicine and social work. Time will not necessarily heal the existing difficulties over co-ordination, confidentiality, 10 and priorities. These could well fester onto the detriment of patients-unless doctors, social workers, 